\title{
Implementation of Basic Physics I Computer-Based Teaching Material on Physics Education Students of Masamus University
}

\author{
Animation Teaching Material of Basic Physics I
}

\author{
Syamsul Bahri ${ }^{1}$, Mitra Rahayu ${ }^{2}$, Supriyadi ${ }^{4}$, Richard \\ Samuel Waremra ${ }^{6}$ \\ Physics Education Department \\ Universitas Musamus \\ Merauke, Indonesia \\ 1'syamsul_fkip@unmus.ac.id, 2rahayu.mitra23@gmail.com, \\ 4supriyadi_fkip@unmus.ac.id, ${ }^{4}$ richard_fkip@unmus.ac.id
}

\author{
Muhammad Arsyad ${ }^{3}$, Kaharuddin Arafah $^{5}$ \\ Physics Department \\ Universitas Negeri Makassar \\ Makassar, Indonesia \\ ${ }^{3} \mathrm{~m} \_$arsyad@yahoo.co.id, ${ }^{5}$ eligakahar@yahoo.com
}

\begin{abstract}
This research is descriptive research. The research aimed to analyze the learning result after using Basic Physics I teaching material to the First Semester Students of Physics Department in Unmus (University of Musamus). The subject of the research is 31 first semester students of Physics Education Department. The data collecting process is conducted by using learning result test instrument. Based on the result of the analysis, the completeness of students learning results after using Basic Physics I teaching materials reaches 97\%, where 7 students obtain A score, 11 students obtain B score, and 12 students obtain C score. Although, there is 1 student who obtains D score which means he/she failed.
\end{abstract}

Keywords-teaching materials; physics learning; computerbased learning; animations

\section{INTRODUCTION}

Recent globalization era demands people to be more competitive in using any available opportunities. Fast globalization flow causes the competition between state and organization sharper [1]. Thus, human resources need to be increased through education in which one of the keys to increase quality. Education will continue to adapt to science and technology development [2]. Moreover, the implementation of education becomes the responsibility and duty of the educator, especially in the indoor or outdoor learning process. Therefore, teacher and lecturer become the main keys of education success in school or college.

Physics has made a great progress in today's technology and information field. It is caused by physic findings which become the basis of modern technology development. Nevertheless, physics material is abstract that consists of concepts, theories, and physics laws which should be remembered by students. Hence, physics need a different teaching material. The teaching material in here is power point based teaching material which completed by supporting aspects such as animation, picture, simulation or any others media.

\section{A. Teaching Material}

Teaching material is a material which consists of knowledge to be shared to students. A teaching material may be defined as a packaging, definition, and explanation of knowledge, experience, and illustration facts systematically and logically. The material is used in a learning process to achieve the learning purpose [3]. Teaching material also can be defined as any forms of media that help teacher/instructor in conducting learning activities in class [2]. Teaching materials that can be developed are: (1) print teaching material such as books, module, student worksheet, and picture; (2) non-print teaching material such as video, audio, and computer; (3) display teaching material such as flipchart, chart or wall chart, poster, photo, and realia [3].

\section{B. Learning Media}

The definition of media in learning process tends to be described as graphic and photographic tools or electronics to capture, process, and re-arrange visual or verbal information. In brief, media is defined as a tool that delivers the content of teaching material [4]. Learning media especially visual media has four functions, they are attention function, affective function, cognitive function, and compensatory function. Attention function is the main function in which draw and direct attention of students to concentrate on the related visual or text learning material [5].

A delivered lesson or subject is often not attractive for students because they do not like it. According to Leshin's taxonomy, et al, learning media is animation based media, print-based media, visual-based media, audiovisual based media, and computer-based [4]. Nowadays, these medias are more developed to be more interactive in order to make students easier in learning. Learning media facilitate the interaction of teachers and students, students and students, and also students and learning resources.

Learning multimedia is a combination of several media such as audio, picture, graphics and the other media that are 
packaged in one form to convey the learning. One of the benefits of interactive multimedia than the traditional learning is the possibility of students to learn based on their own speed. Multimedia has a power to liven up and communicate the dynamic information in a more accurate way than the diagram. It also helps students to visualize the invisible phenomenon [6].

Animation media is the movement of picture or text as if it lives. Text animation is one the animation parts which can be implemented to add effect and beautify the display of teaching material package [7]. Animation media in physics learning is very useful, for example, helping to explain an event too fast too slow down, such as a nuclear reaction or helping explain an event that is too slow to achieve, such as radioactive decay. Media animation is easy to use, for instance, by adding it in media PowerPoint.

Media PowerPoint is one of word processor soft wares that used to display multimedia program. PowerPoint is software that specifically designed to display interesting multimedia program and it is easy to use, relatively cheap as it does not need any tools except data storage [8]. Learning media using PowerPoint very influence the result of study. The use of PowerPoint makes students easily and clearly understands the teaching material with the concrete example [9]. Therefore, the use of PowerPoint media that is equipped with animation in physics learning is very good to use.

\section{The use of Technology and Information in Physics Learning}

Physics is one of the science branches which learn about natural phenomena. The development of physics has given a positive effect on the development of today's technology. Teaching physics is aimed to form a positive manner towards physics in which interested to learn physics further. Physics shows the beauty of the pattern of natural behavior and its ability to explain any natural phenomena also to implement physics itself within technology [10].

Many educators have done researches to solve any problems related to physics learning. One of the research objects is how to visualize physics that has abstract characteristic. The existence of technology and information makes students easier in learning abstract and sub-microscopic concepts [11]. In addition, the benefits of using ICT in physics learning also improve understanding of physics concepts and eliminate physical misconceptions because of the help of media on certain concepts that are very difficult to understand.

\section{RESEARCH METHOD}

This research is descriptive research which is conducted in Musamus University on Physics Education Department, Merauke Regency, Papua. The subject of this research is 31 first semester students of 2016/2017.

The data collection method of this research is conducted by using an instrumental test. This instrument is aimed to discover students' cognitive capacity after learning physics using basic physics 1 computer-based teaching material.

The result of students study may be calculated individually and classically. The result in this research is in form of students score from the test which is given after a lecturer ends. Students are declared pass the test when individually the students obtain minimum 41 score or C. As for the standard assessment and students passing score are presented in Table I.

To determine students passing score individually, it can be calculated using equation (1).

$$
\mathrm{P}=\frac{\sum \mathrm{T}}{\sum \mathrm{N}} \mathrm{x} 100 \%
$$

Information:

$$
\begin{aligned}
& \mathrm{N}=\text { final score } \\
& \mathrm{Sp}=\text { students acquisition score } \\
& \mathrm{Sm}=\text { maximum score }
\end{aligned}
$$

TABLE I. STANDARD OF ASSESSMENT AND STUDENTS' PASSING SCORE

\begin{tabular}{|l|l|l|l|}
\hline Grade & \multicolumn{1}{|c|}{ Score } & \multicolumn{1}{|c|}{ Category } & Information \\
\hline A & $81-100$ & Very good & Pass \\
\hline B & $61-80$ & Good & Pass \\
\hline C & $41-60$ & Satisfactory & Pass \\
\hline D & $21-40$ & Less than satisfactory & Not pass \\
\hline E & $0-20$ & Bad & Not pass \\
\hline
\end{tabular}

Source: [12]

To determine students completeness in learning classically, it can be calculated through equation (2).

$$
\mathrm{P}=\frac{\sum \mathrm{T}}{\sum \mathrm{N}} \mathrm{x} 100 \%
$$

Information:

$$
\begin{aligned}
& \mathrm{P}=\text { classical completeness } \\
& \sum \mathrm{T}=\text { the number of students that passed } \\
& \sum \mathrm{N}=\text { the number of all students }
\end{aligned}
$$

\section{RESULT AND DISCUSSION}

The result of Basic Physics I test is given in order to see how far the students' success in learning through PowerPoint. The result shows that using PowerPoint, students' completeness percentage reaches $97 \%$, in which 7 students obtain A, 11 students obtain B, and 12 students obtain $\mathrm{C}$. The percentage is presented on Figure (1). 


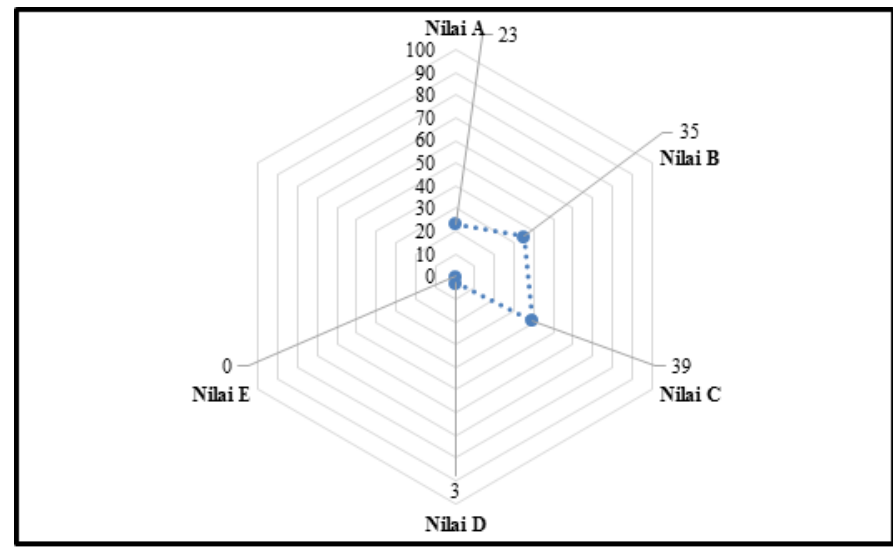

Fig. 1. The percentage of passing score of physics education students on Basic Physics I Teaching Material

Figure (1) shows that the highest percentage of passing score is in C grade. Afterward, it is followed by B and A grades. Meanwhile, students still have not passed percentage on $\mathrm{D}$ grade that is lower than $\mathrm{A}$ and $\mathrm{C}$ grades.

The result shows that using PowerPoint, students' completeness percentage reaches $97 \%$, in which 7 students obtain A, 11 students obtain B, and 12 students obtain C.

The result of study which using Basic Physics I teaching material shows that only 1 person failed out of 31 students. Other 30 students obtain various grades on $\mathrm{A}, \mathrm{B}$, and $\mathrm{C}$ and that one person obtain $\mathrm{D}$. In percentage, students who pass with grade A is $23 \%$, grade B is $35 \%$, grade $\mathrm{C}$ is $39 \%$ and the rest $3 \%$ is D. On average, the level of students pass reaches 69 with grade $\mathrm{B}$.

The high student's completeness cannot be separated from the user of computer-based teaching material. The response of students shows that this media is very effective to be used. The strongest reason is PowerPoint makes students independently learn if the material in class is not finished. The result supported by a study shows that after using computer simulations in physics learning, student mastery the physics concept [13]. The simulation in this learning is integrated into the PowerPoint media in the form of animation.

Besides, by the existence of this media, students are helped from the abstract physics issue. Through this media, students will be helped to visualize several materials which are not enough to be learned through lecturer's explanation. In addition, the use of animation in physics learning also affects the attitudes of students towards learning physics. One of the results of the study shows that the using of animation in physics learning were helpful for more college students' effective physics learning. It would significantly make a positive contribution to students' physics learning attitudes [14].

Other reasons which create high students completeness is illustration/picture within the material. The illustration/picture which represents students daily live makes them easier to understand since it has relation between what they learn and what they see or experience in real life. The use of animation in learning also becomes one of the supporting factors of learning outcomes obtained by students. Many research results support that the use of animation in learning is very good to use. One of the research results stated that the use of animation learning had a very good impact compared to static graphics visualization [15].

After averaging the score, in fact, students' completeness classically only reach 69 or B. This score shows that the capacity of students to understand materials is still average. Other than teaching material, human basic knowledge also becomes the important factor in achieving study completeness. Therefore, this computer-based teaching material is designed with good quality to help students increase their learning result.

Meanwhile, related to the not passed student, if it related to teaching material, later it is discovered that the student has a bad score because of language factor. It can be seen from student low response towards language indicator. The language which is an important element in this teaching material is still considered as a "strange" thing for this student. Hence, the student is hard to understand the material and resulted in the low score.

Another factor that causes student failures is from the used media. The students really expect that the equations in PowerPoint can help them in solving the questions. In fact, students are facing evaluation questions which need analysis. Through deeper investigation, it is known that students expect that all questions in the evaluation test are the same as the example in material. Consequently, it is not media which should be blamed due to the incapability to answer students' task or evaluation, but the students which should be given an understanding that the examples in PowerPoint are only "an example" of equations application. The students also need to be informed that not all examples can represent the questions in evaluation with exactly has the same shape.

\section{CONCLUSION}

The result shows that students passing score is in grade B after using Computer-Based Basic Physics I. Therefore, the use of Computer-Based Basic Physics I can be applied to students of the Department of Physics at the University of Musamus.

\section{ACKNOWLEDGMENT}

We thank Universitas Musamus for facilities, supports, and publications.

\section{REFERENCES}

[1] I. Ruhana, "Development of the Quality of Human Resources Vs Global Competitiveness," J. Adm. Bisnis, vol. 6, no. 1, pp. 51-56, 2012.

[2] F. Eliza, "Development of Interactive Multimedia-Based Teaching Materials Electrical Drawing Courses Using Autocad in the ELectro Engineering Education Study Program FT UNP," vol. 6, no. 2, pp. 6389, 2013.

[3] Ministry of National Education of Indonesia, Technical Guidelines for the Development of High School Teaching Materials." Ministry of National Education of Indonesia- Directorate of High School Development, Jakarta, 2010.

[4] A. Arsyad, Instructional Media, Jakarta: Raja Grafindo Persada, 2010.

[5] A.H. Sanaky, Instructional Media. Yogyakarta: Safiria Insani Press, 2009.

[6] I.C. Panis and O.A. Ki'i, "The Utilizing of Phet Simulation as A 
Computer- Based Learning Media to Improve The Understanding of College Student 's Physics Concepts .," vol. 66, no. Yicemap, pp. 5558, 2017.

[7] M. Adri, "Flash-Case on Text Animation," 2008. [Online]. Available: http://ilmukomputer.com.

[8] T. Nurseto, "Creating an Interesting Learning Media," J. Ekon. dan Pendidik., vol. 8, no. 1, pp. 19-35, 2011.

[9] C.P. Tirtiana, "Effect of learning creativity, use of powerpoint learning media, and family environment on the learning outcomes of accounting subjects in class X AKT of SMK Negeri 2 Blora Academic Year 2012/2013 (Motivation to learn as an intervening variable," Econ. Educ. Anal. J., vol. 2, no. 2, 2013.

[10] M. Kanginan, Physics for $10^{\text {th }}$ Grade of High School. Jakarta: Erlangga, 2006.

[11] K. Wiyono, A. Setiawan, and C.T. Paulus, "Interactive Multimedia Model Based on Learning Styles to Improve Mastery of the Concept of Introduction to Solid Substance Physics," Indones. Phys. Educ. J., vol.
8, no. $1,2012$.

12] Ministry of research, technology and higher education of Indonesia, "Paduan Penyusunan Kurikulum Pendidikan Tinggi," Jakarta: Directorate General of Learning and Student Affairs, Ministry of Research, Technology and Higher Education of Indonesia, 2016, pp. 168.

[13] I. Kaniawati, Y. Hasopa, A.D. Sutrsino, and E. Suhendi, "The Influence of Using Momentum and Impulse Computer Simulation to Senior High School Students' Concept Mastery,” J. Phys. Conf. Ser., vol. 739, no. 1, 2016.

[14] K.D. Su and S.C. Yeh, "Effective Assessments of Integrated Animations-Exploring Dynamic Physics Instruction for College Students' Learning and Attiudes," Turkish Online J. Educ. Technol., vol. 13, no. 1, pp. 88-99, 2014.

[15] S. Berney and M. Betrancourt, "Does animation enhance learning? A meta-analysis," Comput. Educ., vol. 101, pp. 150-167, 2016. 